\title{
Race, prejudice and attitudes toward redistribution: A comparative experimental approach
}

\author{
ALLISON HARELL, ${ }^{1}$ STUART SOROKA² \& SHANTO IYENGAR ${ }^{3}$ \\ ${ }^{1}$ University of Montreal, Canada; ${ }^{2}$ University of Michigan, USA; ${ }^{3}$ Stanford University, USA
}

Abstract. Past work suggests that support for welfare in the United States is heavily influenced by citizens' racial attitudes. Indeed, the idea that many Americans think of welfare recipients as poor Blacks (and especially as poor Black women) has been a common explanation for Americans' lukewarm support for redistribution. This article draws on a new online survey experiment conducted with national samples in the United States, the United Kingdom and Canada, designed to extend research on how racialised portrayals of policy beneficiaries affect attitudes toward redistribution. Aseries of innovative survey vignettes has been designed that experimentally manipulate the ethno-racial background of beneficiaries for various redistributive programmes. The findings provide, for the first time, cross-national, crossdomain and cross-ethno-racial extensions of the American literature on the impact of racial cues on support for redistributive policy. The results also demonstrate that race clearly matters for policy support, although its impact varies by context and by the racial group under consideration.

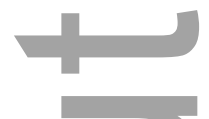

Keywords: redistributive policy; racial prejudice; survey experiments

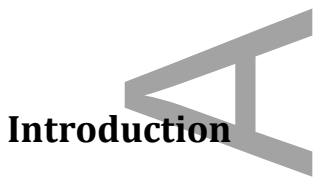

This is the author manuscript accepted for publication and has undergone full peer review but has not been through the copyediting, typesetting, pagination and proofreading process, which may lead to differences between this version and the Version of Record. Please cite this article as doi: $\underline{10.1111 / 1475-6765.12158 .}$.

This article is protected by copyright. All rights reserved. 
As countries become more ethnically and racially diverse, there is increasing concern over continued public support for a shared social safety net (Van Parijs 2004; Soroka et al. 2006; Banting \& Kymlicka 2006; Goodhart 2006; Banting et al. 2006; Crepaz 2007; Koopmans 2010). There is nevertheless relatively little comparative research that examines the direct impact of citizens' attitudes about diverse others on support for specific welfare state policies - at least outside of the American context.

Racial attitudes have long played an important role in shaping Americans' policy preferences (Kinder \& Sears 1981; Hutchinson 2009). This is especially true for programmes designed to address poverty, particularly 'welfare'. There is a considerable body of work suggesting welfare is 'race-coded' - that is, Americans tend to think welfare recipients are disproportionately black, and support for welfare is significantly lowered among people who hold negative attitudes toward blacks (Iyengar 1990; Gilens 1995, 1996a, 1996b, 1999;

Mendelberg 2001; Nelson 1999; Federico 2005; Lee \& Roemer 2006; Schram et al. 2003; Winter 2006, 2008).

This conflation of race and 'welfare' is often discussed - in work in the United States at least - as a uniquely American phenomenon. There are growing signs that it is not. Recent work points to the racialisation of welfare in the Canadian context (Harell et al. 2013) and in Europe (Wright \& Reeskens 2013; Ford 2006, 2015). This complements a longstanding body of work on welfare-chauvinistic parties in Western Europe (e.g., Freeman 2009; Van Der Wall et al. 2013) and growing literatures on the tension between diversity and support for the welfare state as well (for recent reviews, see Nannestad 2007; Stichnoth \& Straeten 2013; Soroka et al. 2015; though also see Evans 2006). Much of this work points to the generalisability of what is sometimes viewed as a distinctive American story.

The overlap between findings in the United States and elsewhere is limited by the fact This article is protected by copyright. All rights reserved. 
that American work on welfare support typically focuses on blacks, whereas work elsewhere focuses on the diversity introduced by recent immigration, which may or may not be directly linked to race. Indeed, much of the European literature focuses on the impact of diverse immigration - not directly on support for welfare policies currently available to racially different minorities. The aim of this article is thus to offer one of the first directly comparable tests of the impact of racial bias on social welfare preferences, focused on specific welfare state policies in a cross-national context. The analysis covers multiple racial groups, a variety of social welfare programmes and several liberal welfare states. Drawing on a unique parallel online experiment conducted in the United Kingdom, Canada and the United States, we focus on one relatively simple, but fundamentally important, research question: How do racial cues and racial attitudes influence support for welfare state benefits?

Our findings suggest that support for redistribution is indeed racialised. Unlike most past research that focuses on blacks in the United States, we show that the racialisation of welfare attitudes extends beyond this racial minority, beyond welfare and beyond the American context. Indeed, our evidence indicates that relative to the United States, recipient race affects support for social programmes equally if not more so in the United Kingdom, and to a lesser extent in Canada as well; and that the effects are evident for different races/ethnicities and hold across a range of welfare state policies. There is heterogeneity in the impact of racial cues: they are particularly powerful for individuals with pre-existing racial prejudice. Racial bias thus not only exerts powerful direct effects on welfare attitudes, but also moderates the impact of racial cues in our experimental treatments. The end result is, we believe, a powerful demonstration of the relevance of racial bias for understanding attitudes toward social policy.

\section{Race and welfare}

This article is protected by copyright. All rights reserved. 
One of the recurring themes in the debate in the United States on support for welfare, defined in terms of means-tested social assistance programmes, concerns the racial composition of the beneficiary class. Unlike programmes like social security that promoted integration among white middle-class (male) workers through a national, universal programme structure; programmes for the poor, like Aid to Families with Dependent Children (AFDC), targeted an increasingly feminised and disproportionately black underclass (Lieberman 1998). Public support for welfare in the United States is thus inextricably intertwined with the racial cleavage between whites and blacks (Gilens 1995, 1996a, 1999; Mendelberg 2001; Schram et al. 2003; Winter 2006).

When whites associate welfare benefits with race (by identifying beneficiaries as black), they tend to be less generous toward welfare recipients and to view them as less deserving (Iyengar 1991; Gilens 1999). The reason for this association is twofold. First is an underlying intergroup dynamic. Work in social psychology has consistently pointed to people's tendency to favour their own group members and to express hostile and negative attitudes toward out-group members (Allport 1958; Blumer 1958; Sherif et al. 1961; Tajfel \& Turner 1986). When recipients of welfare are viewed as representing an out-group, evaluations of their deservingness and eligibility are coloured by feelings and stereotypes about that out-group (Nelson 1999). When it comes to welfare, we know that citizens tend to overestimate the number of blacks on welfare (Gilens 1999: 68). We also have extant evidence that out-group prejudice towards blacks is correlated with less support for welfare among the white majority (Gilens 1995; 1996b; 1999; Nelson 1999; Federico 2005; Lee \& Roemer 2006; Winter 2008).

In addition to the in-group-out-group dynamic, there is a more programme-specific discourse in American culture that intersects with the racial divide. The norms of rugged 
individualism in the United States stigmatise welfare recipients who are perceived as able but unwilling to work (Golding \& Middleton 1982; Katz 1989; Gilens 1996b; Clawson \& Trice 2000; Misra et al. 2003; Somers \& Block 2005; Kluegel \& Smith 1986). As Katz (1989: 10) notes: 'The issue [in poverty discourse] becomes not only who can fend for themselves without aid, but more important, whose behavior and character entitle them to the resources of others.' The issue of deservingness is further exacerbated because welfare is also seen as a programme that creates perpetual welfare recipients by creating perverse incentives not to work (Somers \& Block 2005).

Racial perceptions, at least in the American context, come into play when deservingness arguments are evoked. While old-fashioned racial stereotypes often focused on blacks' perceived biological differences related to capacity (e.g., lower intelligence), more recent forms of racism tend to focus on cultural values, such as the work ethic (e.g., laziness). When asked to explain economic inequalities between whites and blacks, citizens often reject structural explanations in favour of individualistic ones (Kleugel 1990; Bobo 2001). And individualistic explanations tend to cite blacks' lack of motivation or willingness to work hard, rather than their innate ability (Bobo 2001: 282-283), reflecting a shift away from (at least overt) expressions of old-fashioned racist attitudes.

Recipient deservingness is thus often assessed through the lens of racial schemas that activate underlying predispositions about group characteristics. According to Winter (2008: 37-40), racial schemas in the United States - in keeping with the underlying distinction between in- and out-groups - characterise the black out-group as 'lazy, dependent and poor', in comparison with hardworking whites (Winter 2008: 38). For Gilens (1999), these stereotypes are key to understanding low levels of support for welfare among white Americans. Because they think welfare recipients are overwhelmingly black, and because they tend to view blacks as lacking in work ethic, whites tend to be hostile to welfare 
programmes. Fox (2004) has further shown that concerns about the work ethic extend to whites' support of welfare benefits directed at Latinos. In other words, racial prejudice is likely to activate, accentuate and distort considerations of deservingness, which themselves are more likely to motivate policy support when means-tested programmes are under consideration.

The racialisation of welfare argument thus relies on the perpetuation of racial stereotypes, alongside a continued over-representation of blacks in news media coverage of welfare programmes. Gilens (1996a; 1999) shows that the news media over-represent black welfare recipients relative to their actual programme usage. Furthermore, blacks are especially over-represented in the least sympathetic stories: those about unemployed adults and the cycle of welfare dependency (Gilens 1996a; Clawson \& Trice 2000; Misra et al. 2003). This is in contrast to stories that focus on groups viewed as more deserving, such as the elderly and the working poor (Iyengar 1990; Cook \& Barrett 1992), which tend to underrepresent black recipients.

Work on race and policy attitudes in the United States extends beyond social assistance programmes. There are related literatures focusing on affirmative action (e.g., Bobo \& Kleugel 1993; Krysan 2000; Feldman \& Huddy 2005), health care (Tesler 2012) and crime (e.g., Peffley et al. 1997; Hurwitz \& Peffley 1997; Mendelberg 2001; Peffley \& Hurwitz 2002; Gilliam et al. 2002; Federico \& Holmes 2005). As with welfare, media coverage of crime paints it as a disproportionately black problem, and consistent evidence suggests that when blacks are portrayed as violent criminals, whites support harsher punishments (Gilliam \& Iyengar 2000). Racial attitudes are thus related to a host of policy domains that feature visible racial cues. So, while the literature on welfare points to the intersection of racial attitudes with assessments of deservingness, other literatures point toward the pervasiveness of racial attitudes in shaping policy judgments. 
The comparative literature - across policy domains and across countries - has remained relatively silent on the role of racial attitudes in support for social welfare policies. ${ }^{1}$ Much of the comparative European literature on the welfare state focuses on the impact of immigration and ethnic diversity on support for the welfare state (for recent reviews, see Nannestad 2007; Sticknoth \& Straeten 2013; Soroka et al. 2015). For example, Crepaz (2007) argues that population homogeneity allowed for the development of generous European welfare states because intergroup competition for resources was less likely when shared ethnic identity overlapped national identity. Interestingly, Wright and Reeskens (2013) show that strong ethnic conceptions of national identity have a negative impact on support for welfare. Luttmer (2001), Finseraas (2008) and Mau and Burkhardt (2009) further show that ethnic heterogeneity has a negative impact on support for welfare state redistribution, while Reeskens and Van Oorschot (2012) show that higher levels of immigration are related to citizens' willingness to place more restrictions on immigrants' access to welfare benefits. This body of literature is focused on the impact of actual diversity (rates or levels of immigration, or measures of ethnic heterogeneity), however, and much less on the impact of attitudes about diverse others.

Work on the connections between racial and ethnic prejudice and support for redistribution is much more limited. Faist (1995), in a comparison between the United States and Germany, has argued that while welfare state support has always been racialised in the former, rising levels of immigration in the latter has led to a shift from a class-based to an ethno-class-based cleavage around support for the welfare state. Ford (2006) shows that prejudice has a negative effect on general support for the welfare state in the United Kingdom. He also shows that when confronted with ethnic minority or immigrant welfare claimants, Britons consistently show less support (Ford 2015; also see Soroka et al. 2013). Hjorth (2015) finds that cues about 'cross-border' welfare recipients within the European This article is protected by copyright. All rights reserved. 
framework leads to greater welfare chauvinism and that this interacts with pre-existing ethnic attitudes. Other work also finds evidence that racial cues and racial prejudice decrease support for Aboriginals on social assistance in the Canadian context based on separate data (Harell et al. 2013). To the best of our knowledge, these are the only studies to test directly the influence of racial cues on support for specific welfare state policies outside the American context, and there is no study that looks at the combined roles of racial prejudice and racial cues across policy domains. These prior studies nevertheless suggest that there is good reason to think that racial cues and racial attitudes will influence people's attitudes toward welfare state policies.

This expectation is further supported by research showing that there are important ethno-racial hierarchies outside of the United States that put ethnic and national majorities at the top, although there is some debate about how exactly various minority groups rank (Bleich 2009; Ford 2008). What is clear is that prejudicial thinking toward ethno-racial and religious minorities is not unique to the American context, and it is reasonable to assume that such attitudes, at least some of the time, can be activated to influence public opinion elsewhere (see, e.g., Blinder et al. 2013). Furthermore, there is reason to believe that policy domains that are means-tested are particularly likely to link recipient characteristics, and particularly their deservingness, to public support (Larsen \& Dejgaard 2013; Rothstein 1998; though see Aarøe \& Petersen 2014).

Some explanatory factors have been studied in considerable detail: for instance, selfinterest and political predispositions have been shown to be powerful drivers of attitudes about redistributive policy (Hasenfeld \& Rafferty 1989; Bobo 1991; Cook \& Barrett 1992; Feldman \& Zaller 1992; Sniderman \& Carmines 1997); and those who espouse more egalitarian values also tend to be more supportive of the welfare state (Bobo 1991). Yet thus far we know very little about how racial biases affect policy support cross-nationally, even 
though the intergroup dynamic that underpins this relationship is broadly generalisable.

\section{Data and methods}

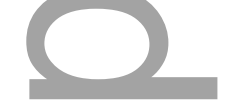

Our analyses explore how racial cues and racial attitudes influence public support for welfare state policies. In the first case, we examine the direct effect of a racial cue on support for redistribution across five policy domains. Consistent with research on stereotypes and intergroup dynamics, we expect that a beneficiary perceived as a racial minority will be awarded lower levels of cash benefits as compared to a white beneficiary, especially when dominant stereotypes associated with that racial group include negative traits related to the work ethic, as in the case of black stereotypes in the United States. Conversely, 'model' minority groups, whose stereotype is more favourable (e.g., Asians in the United States), will be treated less harshly. In the second case, we not only assess the effect of racial stereotypes on redistributive policy attitudes, but also consider the extent to which racial prejudice interacts with recipient race. We expect those with higher levels of racial bias to be less willing to dispense cash benefits in general and that the effects of the beneficiary's race will be stronger among respondents with higher levels of racial bias.

The data used for this analysis are drawn from the Race, Gender and the Welfare State (RGWS) survey, which was fielded online in July 2012 in the United States, Canada and the United Kingdom ( $\mathrm{N}=1,200$ per country). An additional subsample of 600 respondents was collected in the United States in May 2013, ${ }^{2}$ and we were also able to include 509 'incompletes' from the United States, bringing that sample up to 2,309 for some analyses. ${ }^{3}$ Each survey was fielded by YouGov-PMX, which uses a matching methodology for delivering online samples that mirror target populations on key demographics. For details on the sampling procedures and composition of the YouGov online panels, see Vavreck and 
Iyengar (2011).

The selection of these three countries reflects a 'most similar systems' design. All three are considered liberal welfare states, each has significant levels of racial and ethnic diversity, and each has experienced significant economic retrenchment (albeit to varying degrees) in recent years. These countries also have the practical commonality of having large English-speaking populations, meaning that the survey instrument can be conducted in a common language in each country, minimising the risk of inter-country differences resulting from survey instrument translation. (That said, in Canada, the survey was conducted in both English and French to ensure national representativeness.) In addition, there is reason to believe that negative attitudes toward the poor are prevalent in all three nations, although most of the evidence derives from the United States (see, though, Golding \& Middleton 1982; Harell et al. 2008, 2013).

\section{Measuring racism}

We know that racial attitudes are an important factor in understanding support for redistribution. Yet, measuring racial prejudice is not an easy task. There are numerous approaches to defining and operationalising racial prejudice, and associated debates over its causes and consequences (for an overview, see Bobo \& Fox 2003). While a detailed review of the relevant literature is beyond the scope of this article, we note that all of these approaches view racial prejudice as resulting from an underlying intergroup dynamic. An out-group is viewed as a collectivity rather than a set of individuals, and the group is perceived negatively vis-à-vis one's in-group. Simply cuing group identity, in many cases, is sufficient to activate out-group hostility (Sherif et al. 1961; Tajfel \& Turner, 1986).

In the United States, one of the most contentious debates in the racial attitudes 
literature addresses whether prejudice against blacks has decreased over time, or whether their public expression has simply become more subtle (e.g., McConahay \& Hough 1976; Kinder \& Sears 1981; Schuman et al. 1997; Pettigrew \& Meertens 1995). Blatant forms of racism, such as the expression of explicitly negative racial stereotypes, may have declined, not because the stereotypes have changed, but because it has become socially unacceptable to express them. In response to the diffusion of egalitarian norms, whites have adopted 'modern' or 'symbolic' forms of prejudice based on beliefs that blacks violate mainstream American values such as individual achievement and the work ethic (Henry \& Sears 2002).

There is a further debate over whether indicators of modern racism are valid measures of prejudice (Sniderman \& Carmines 1997; Carmines et al. 2011). While we take no position on this issue, the debate highlights the importance of measuring racism in all its forms. For the sake of parsimony, we begin with just one measure of 'overt' racism here. An online appendix includes a replication of our findings using three different measures of racism (overt, modern and implicit); the evidence given there suggests that, at least for the effects on which we focus, the various measures of racism all point in the same direction.

'Overt' or 'blatant' racism is measured here using a 0-1 scale based on two questions that tap negative racial stereotypes. Using the example of Canada, the questions are worded as follows:

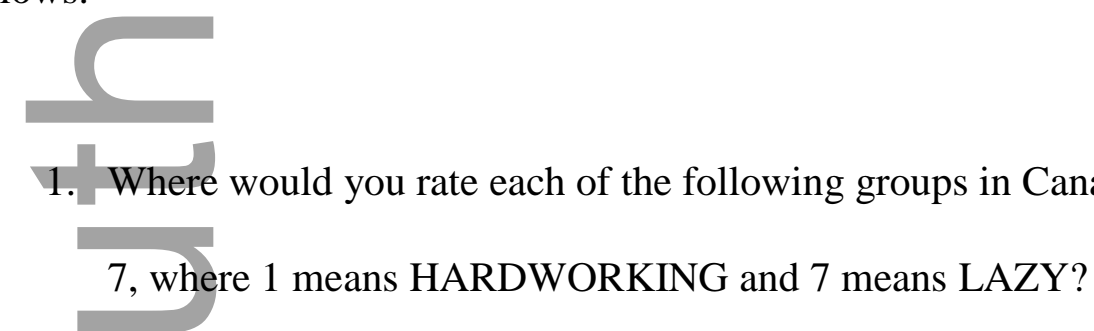

2. Where would you rate each of the following groups in Canada on a scale of 1 to 7, where 1 means DEPENDENT and 7 means SELF RELIANT?

These items are a subset of the standard racial stereotypes battery used in the General Social This article is protected by copyright. All rights reserved. 
Survey and the American National Election Surveys. We rely here on two traits that the race and welfare literature (as well as the modern racism literature) identify as particularly important to the link between blacks and welfare due to their relationship to the deservingness frame. These overt racism questions also have the benefit that we are able to target different racial groups of interest: Aboriginals/Native Americans, ${ }^{5}$ Asians (e.g., Chinese), Blacks, South Asians (e.g., Indians, Pakistanis) and Hispanics.

\section{Experimental vignettes}

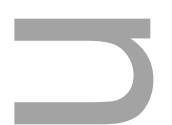

To examine the effects of racial cues and racial attitudes on support for redistributive policy, we developed seven experimentally manipulated policy vignettes, using a factorial design (Rossi \& Nock 1982). Each vignette is treated as the unit of analysis in a repeated, or withinsubject, experimental design. In total, we have as many as 32,963 respondent-vignette pairs (4,709 respondents*7 vignettes each), and 21,082 respondent-vignette pairs when we limit the analyses to white, non-foreign-born respondents (with non-missing data on the variables of interest).

The vignettes are short stories about individual policy recipients, including a photograph, that describe the fictional recipients' personal situation and the amount they would be eligible to receive as cash benefits. (See the online appendix for the full text of all vignettes.) The eligible amount is calculated as the average amount of support for a person in the described situation, based on actual benefits in place in each country as of $2012 .^{6}$ Following presentation of the vignette, the respondent is asked what level of benefits the target recipient should receive on a scale ranging from US\$0 to twice the eligible amount, where the starting point for the slider is the middle of the scale, so that respondents can drag benefit levels either up or down from the midpoint representing the present amount received. 
For the analyses below, we focus on the percentage change in support based on the amount offered in the vignette, allowing us to combine and compare results across countries and domains on a similar metric.

The vignette approach provides a useful alternative to establish attitudes compared to traditional survey items, despite its less common use in political science. Vignettes allow people to make specific judgments that are often easier to report compared to feelings about abstract values (Alexander \& Becker 1978). They have the added benefit of being ideally suited to experimental manipulation because respondents can be randomly assigned to different versions of the scenario (as well as randomly assigned to the order of presentation to minimise sequence effects). This is especially important when racial attitudes are considered. As we have noted, overt racial animosity has decreased over time, yet people continue to express more subtle forms of racism (Kinder \& Sears 1981). Given increasing social pressure to refrain from overt forms of racism, asking directly about racial attitudes can induce social desirability bias in responses. The online vignette has the additional advantage of allowing us to take advantage of visual cues not normally available in traditional survey methodology.

Our seven vignettes (presented in a random order) focus on five policy domains: welfare, benefits for low-income seniors, unemployment insurance, parental leave benefits, and disability benefits. Each vignette experimentally manipulates the race of the recipient. In the United States and Canada, we include white, black, Asian and Native recipients. The American study also included Latino recipients. In the United Kingdom, we included white, black, Asian and South Asian recipients. ${ }^{7}$ 'White' is treated as the control category in all analyses. The ethno-racial categories were selected in each country to include blacks for direct comparison to the American context. Asians (and South Asians in the United Kingdom) were selected to represent a large immigrant population within each country that is relatively well-off and not necessarily linked to welfare discourses. Finally, Native 
Americans (Aboriginals) were included as a non-immigrant ethno-racial minority in both Canada and the United States. Like American blacks, Native populations in both countries face important issues surrounding poverty (Cornell 2006), and are targets of pernicious stereotypes related to the work ethic (Tan et al. 1997; Harell et al. 2013). Finally, an additional-sub-sample was collected in the United States which included Latino cues across vignettes. Given the size of the Latino/Hispanic community in the country as well as recent work on the link between attitudes toward Latinos and welfare support (Fox 2004), this category was viewed as essential for understanding the power of diverse 'racial' cues in the American context.

We cue the race of the recipient in two ways. First, using a face-morphing program (FaceGen Modeler), we start with a base photograph and then blend in prototypical ethnic morphs. ${ }^{8}$ The resulting photos are edited further to add in age characteristics, hair and clothing that are identical across morphs. We rely on morphed photographs because it is important that we control for other facial characteristics (such as attractiveness) known to affect social judgments (see, e.g., Eagly et al. 1991; Eberhardt et al. 2004). By beginning with the same base face, blending this face with identical morphs and adding other identical features, we largely eliminate the influence of these potential confounds. In addition to race, several of the vignettes also vary the gender of the recipient, so models include controls for this attribute.

In addition to the non-verbal manipulation, the vignettes vary the name of the recipient, using common ethnicised male and female names associated with the different ethno-racial groups. For instance, one vignette uses the following male names: Jay Smith (white), Jamal Williams (black) and Jiang Lee (Chinese); and the following female names: Laurie Smith (white), Latoya Williams (black) and Lian Lee (Chinese). We examine the independent effects of the race manipulations - both verbal and visual - on respondents' level 
of generosity toward the target recipients. We are also able to assess the joint effects of racial cues and racial attitudes by interacting the racial manipulations with our indicators of prejudice. The bulk of this latter analysis uses the measure of overt racism since it was asked of each racial group in all countries. Parallel analyses of symbolic and implicit measures of racism are available in the online appendix.

Our analyses of variation in benefits awarded to the target recipients include several control variables. We control for the order in which the respondent sees the vignettes (numbered 1 to 7), as well as a set of dummy variables for each of the seven vignettes. These variables soak up whatever effects are attributable to policy domains and other sources of cross-vignette variance. The result is that the coefficients for all other variables capture their within-vignette impact. Finally, for the United States, we add an additional dummy variable (Wave) to separate the respondents who completed the study in May 2013.

We present a pooled analysis in which each respondent-vignette combination is a separate case. This allows for a panel estimation that is ideally suited for capturing the impact of racial cues, alongside other factors, averaged across vignettes.

\section{Analysis}

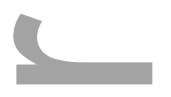

(1)

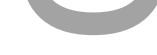

We include the full results of all estimations in the online appendix. Here, we focus on the most important (for our purposes) results: the impact of racial cues, both alone and alongside measures of overt racial bias. Figure 1 presents the effect of racial cues for each country separately (based on models included in Table A1 in the online appendix). The figure shows the average percentage change in financial support awarded to the target recipient, where 0 represents the actual level of support received, derived from a basic model including no measures of racial bias. Our expectation is that recipients representing racial minorities will 
be treated as less deserving of support than whites. Based on the literature, this should be particularly true for black recipients in the American context.

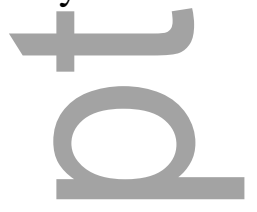

\section{[INSERT FIGURE 1 ABOUT HERE]}

口

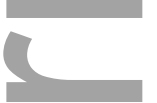

In fact, we find very little evidence of racial bias in the amounts awarded by American participants. While the estimated percentage change in financial support awarded is highest for whites (who receive a slightly positive increase in support), none of the differences across racial groups are significant. American respondents, on average, defer to the status quo, giving recipients amounts very similar to current levels, no matter the ethnicity of the recipient.

Canada and Britain both provide stronger evidence of race-based judgments of deservingness. The effect is clearest in the United Kingdom where black, Asian and South Asian recipients all receive significantly less in relation to the white baseline condition. While participants cut the white recipient's benefits by about 4 per cent from the status quo, they treat minority recipients even more harshly, cutting their benefits by $7-10$ per cent, with blacks receiving the lowest levels of support. Canadian respondents proved more generous to recipients across the board, with all recipients allocated higher levels of support than the current level. Nonetheless, there are traces of racial bias; Canadians are less generous (i.e., award smaller increases over the current benefit) toward Asian recipients and, to a lesser extent, Aboriginal Canadians. ${ }^{9}$

The results in Figure 1 thus provide some support for the hypothesis that white respondents are less supportive of welfare assistance directed at racial minorities. We are faced with a puzzling result, however: in spite of the large American-focused literature motivating our analysis, we find that racial cues matter in the United Kingdom and Canada 
but not in the United States.

We are not inclined to believe that race does not matter to welfare attitudes in the United States. Table 1 shows the mean scores on our measure of overt racism by country. Recall that this measure consists of two questions tapping the extent to which each minority group is perceived to have two negative qualities (lazy and dependent) that have traditionally been associated with blacks in the United States. On this measure, racism is clearly strongest for blacks in the United States $($ mean $=0.45)$, and weakest for Asians $($ mean $=0.19)$. South Asians, Hispanics and Native Americans receive overt racism scores somewhere in-between. Thus, the racial hierarchy in the United States clearly places blacks at the bottom when it comes to explicitly negative stereotypes.

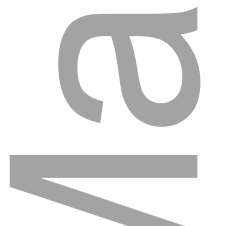

[INSERT TABLE 1 ABOUT HERE]

The overt racism scores for Britain exhibit a similar pattern: on average, blacks receive almost an identical score to the US (0.45), and South Asians and Asians are rated more favourably than blacks, although they are viewed somewhat more negatively than in the United States. In Canada, blacks elicited more favourable trait ratings than in either the United States or the United Kingdom (0.36), but the racial hierarchy vis-a-vis Asians and South Asians remained intact - that is, Asians and South Asian stereotypes are less negative. As past research has suggested (Harell et al. 2013), Aboriginal peoples in Canada face significant prejudice. They are, in fact, the only group across the three countries for whom the mean overt racism score is above 0.5 .

Given the considerable individual-level variance in these measures of prejudice, it follows that the impact of racial cues on support for welfare policies might be particularly strong for some (overtly racist) respondents, but weak for other (less racist) respondents. 
Overt racism may also directly impact policy support with more racist respondents favouring less generous benefits. Recall that we have overt racism scores for each racial category, and can thus explore both possibilities by interacting particular racial cues with relevant racism scores (e.g.m black beneficiary x overt racism toward blacks). Table 2 present results speaking just to the second issue: what is the direct impact of overt racism on policy support?

[INSERT TABLE 2 ABOUT HERE]

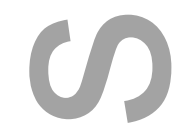

The table shows coefficients for overt racism, drawn from the full estimations in Table A2 in the online appendix. In brief, the results suggest that the small differences in support across racial groups in Figure 1 are the product of countervailing tendencies among high- and low-prejudice respondents. First, let us consider the American case. Table 2 makes clear the significant relationship between overt racism and policy support: those who express overt prejudice consistently award less support across the five redistributive policy domains. ${ }^{10}$ In the United States, the effects of overt racism hold for both black and Native American recipients and the impact is strongest for the former. This is exactly as we should expect given the literature: there is a link between racism toward blacks and Americans' support for redistributive policies, even independent of whether the target recipient is perceived as black. (Note that the coefficients are easily interpreted: a move across the scale in overt racism toward blacks is associated with an average 43-point decrease in the percentage change in support offered by respondents.) In the United Kingdom, too, there is a powerful negative effect of overt racism toward blacks, and a smaller one for South Asians. In Canada, it is only overt racism toward Aboriginals that affects policy support.

The impact of both racial cues and overt racism is clearer still when we take the interaction effects into account. Figures $2-4$ show results for the United States, the United 
Kingdom and Canada, respectively (again, results are based on models in Table A2 in the online appendix). Each figure graphs the estimated percentage change in support based on the race of the recipient (as compared with white recipients) interacted with the respondents' overt racism (toward the relevant race). The solid line represents respondents with a high level of overt racism, and the dashed line represents those with low overt racism scores.

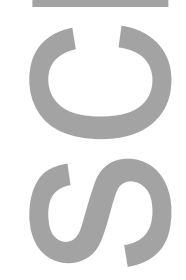

\section{[INSERT FIGURES 2-4 ABOUT HERE]}

The pattern for black recipients in the United States sets out the expected relationships clearly. There is a direct, negative impact of overt racism (toward blacks) on the benefits awarded. In addition, when presented with a black recipient, those with lower overt racism tend to increase benefits above and beyond current levels, while those with higher levels of racism tend to cut benefits. This results in a widening of the gap between black and white recipients by nearly 30 points. This result is not contingent on our measure of racism, either parallel analyses using a modern racism scale or an implicit measure of bias against blacks yield similar results. ${ }^{11}$

A similar dynamic is evident for Native recipients. For Asians, however, the results are more complex. We skipped over the positive coefficients for Asians in Table 2 as they are a little misleading, but Figure 2 helps clarify this relationship. Those who are openly prejudiced against Asians give markedly more money to whites, but less to Asians. We suspect this reflects the perceived economic position of Asians vis-à-vis the other ethnic groups: concerns about Asian economic success leads prejudiced respondents to give whites more money. Those who express low levels of overt racism toward Asians, however, treat white and Asian recipients no differently. Finally, the benefits awarded to Hispanic recipients are not moderated by expressed racism toward Hispanics, though a small (but insignificant) 
direct effect of racism is evident here. These null results may be a function of a smaller sample size; it may also suggest something distinctive about the impact of racial bias toward Hispanics.

Figure 3 presents results for the United Kingdom, where we find a pattern with black recipients that is similar to the United States. Again, when the recipient is black, non-racist individuals increase the level of support over current funding, whereas racists recommend reduced support. As we have already seen, the measure of prejudice has a powerful direct effect as well. Also in keeping with the American results, the moderating effects of prejudice are weaker for the two other racial minority groups. For Asians and South Asians, the racial cue matters only for racists; those with low racism scores make no distinction between white and Asian/South Asian recipients. Canada is unlike the United States and the United Kingdom in that Canadians do not discriminate against black recipients. Nor is there any apparent bias against Asian recipients. The solitary case of Canadian prejudice is directed toward Aboriginal recipients; overtly racist attitudes toward Aboriginals have a substantial effect on the support awarded to an Aboriginal recipient. The 65-point gap in support is the largest penalty incurred by any minority group across the three countries, although it is roughly the same as the reduction in support for blacks in the United States and the United Kingdom. In other words, while Canadians appear to behave in an egalitarian manner when supporting redistribution for immigrant racial minorities, they are by no means benevolent and unprejudiced toward Aboriginal peoples.

\section{Conclusions}
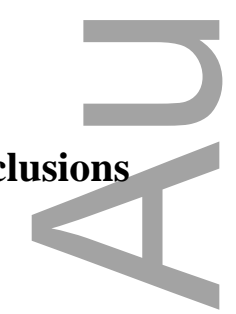

Race matters when it comes to public support for redistribution. Yet, as our analysis clearly demonstrates, the influence of racial cues and racial prejudice varies by context and across 
particular racial minority groups. In the United States, we find that racial cues directly affect support for redistribution to individual recipients with black recipients being subjected to discriminatory treatment. This 'racialisation' effect is conditional on respondents' preexisting racial biases, where higher levels of racism dramatically enlarge the effects of the racial cues. Blacks are not the only group subject to discrimination, though: white respondents with high levels of prejudice also display bias against Native American and Asian American welfare recipients.

We find parallel evidence in the United Kingdom and, to a lesser extent, in Canada. Those in the former tend to be less generous than their American counterparts, especially toward racial minorities, and this support is especially low when prejudiced individuals are confronted with a minority recipient. In the latter, citizens tend to be relatively generous in their support to immigrant-based racial groups, although their generosity does not extend to Aboriginal recipients.

Do the results obtained above matter for general attitudes towards redistribution, or are they specific to attitudes directed towards (hypothetical) individual recipients? Our use of vignette-based experiments gives us a good deal of leverage over the specific characteristics of recipients, and it allows us to be very precise in our description of benefits as well. We regard the vignettes as a particularly powerful way of getting at the impact of race on welfare-state attitudes. But it is reasonable to ask whether the connections between racial bias and support for social policy evident in these experimental data also apply at a more general level. This spilloyer is testable. Indeed, the online appendix includes a detailed comparison of our individual-level results and results where general support_for social programmes is the dependent variable. These models make clear the degree to which our experimental results spill over to models of welfare state support more broadly: overt racism not only has an impact on (a) support for spending on particular beneficiaries (from experiments), but also a 
direct and significant negative impact on (b) support for generalised government action (from survey questions).

This study has several implications for understanding the relationship between group identity, group stereotypes and support for welfare state policies. Most importantly, our results suggest that the largely American literature about the racialisation of welfare attitudes among whites towards blacks is more generalisable than some past work suggests. The relationship between welfare attitudes and racial attitudes in the United States is certainly tied in part to its unique history, but our evidence makes clear that other racial groups in other nations are stereotyped similarly and subject to the same form of discrimination. This is of real significance: immigration is clearly changing the racial and ethnic composition of European and North American populations, and this has raised serious debates about the state of social solidarity in diverse societies (Crepaz 2007, Koopmans 2010). Redistributive policies are one of the key ways in which the state addresses economic inequality, yet this study suggests that racial bias is a major impediment to public support for such programmes, and this is neither limited to social assistance programmes nor specifically to the unique history of slavery and racial discrimination that characterises race relations in the United States.

The significance of these findings is underscored by the fact that American media coverage of redistributive policy domains is often both personalised and racialised (Iyengar 1990; Gilens 1999). We suspect that such racialised coverage is not limited to this context or to this particular group: issues around immigration and the welfare state in the European context also regularly draw on racialised discourses around deservingness. And our results make clear the extent to which simply cuing the racial background of recipients can influence support for an essential component of the welfare state.

The variation observed in this study, across groups, policies and countries may in part This article is protected by copyright. All rights reserved. 
be explained by how dominant such associations are between each group and policy across these three liberal welfare states. Explaining this variation will be the focus of future work. So, too, will a consideration of the degree to which our findings extend beyond liberal welfare states. There is reason to believe that liberal welfare states that rely primarily on means-tested programmes will make recipient considerations more likely (e.g., Larsen \& Dejgaard 2013; Rothstein 1998). Past work on media coverage also points towards this possibility - for instance, Aarøe and Petersen (2014) show that media coverage of welfare recipients is much more likely to mention with black racial steretoypes (e.g., laziness) than similar coverage in Denmark. Larsen (2013) also finds that media coverage in the United States and the United Kingdom tend to be far more negative about welfare recipients than in Sweden and Denmark. It may be the case that liberal welfare states tend to promote a public discourse that highlights specific characteristics of recipients.

Note that our vignettes were not limited to means-tested programmes - indeed, half of them were contribution-based. Our study thus shows that when associations are made between recipients of various programmes, and their ethno-racial background, then we expect racial prejudice to decrease support. While other welfare type regimes might be less likely to draw this association, when it does occur we would expect similar results to emerge. This, of course, is conjecture and requires empirical testing, but with increasing pressure on welfare states, combined with new and increasingly diverse immigration to Europe, there is good reason to expect that media discourse will increasingly link the who with welfare benefits. If this occurs, we expect that a broad range of policies will become racialised. Support for redistributive programmes, across a wide range of welfare states, may decline accordingly.

\section{Notes}

This article is protected by copyright. All rights reserved. 
1. This is not to say that there is no work on racial and ethnic prejudice and policy there is certainly work on other policies, such as immigration and support for accommodation. See, e.g., McLaren and Johnson (2007) and Blinder et al. (2013).

2. The additional American sample was identical to the original, except Asian and Native American beneficiaries in the vignettes were replaced with Hispanics, allowing for an additional ethno-racial cue for the United States.

3. The vignettes (described below) were early in the survey, so for most of our analyses even the 'incompletes' (i.e., those who did not finish the survey) have provided the responses we need.

4. While YouGov does not provide a true probability sample, research suggests that analyses of causal effects tend not to be influenced by potential selection biases (e.g., the tendency of online panelists to be more politically interested) (Simmons \& Bobo 2015). Moreover, the YouGov matched samples have achieved impressive rates of predictive validity, accurately predicting the outcome of several national, statewide and local elections, with an average error rate comparable to what would be expected given random sampling (Rivers \& Bailey 2009; Vavreck \& Rivers 2008). YouGov polls on a regular basis for several major news organisations, including The Economist and New York Times.

5. Note we use these terms interchangeably. 'Aboriginal' is the term most often used in the Canadian context, while 'Native Americans' is used in the United States (and our surveys reflect these differences in terminology). Both refer to descendants of the peoples that populated the continent prior to European settlement. To simplify the tables, we use the term 'Aboriginal' in both the United States and Canada.

6. Note that for parental leave in the United States, no comparable public programme exists. Here, we rephrase the vignette to say the recipient is eligible for a new parental 
leave benefit based on the approximate levels available under temporary disability benefits in the five states in the United States that offer such programmes.

7. To be clear, we use 'Asian' here to refer to, e.g., Chinese, Vietnamese and Korean immigrants; and 'South Asian’ with reference to, e.g., Indians, Pakistanis and Sri

Lankans.

8. Note that a proto-typical face for Native Americans/Aboriginals is not available in FaceGen. The authors used a combination of morphs to achieve a stereotypical Native recipient.

9. Note that only the Asian estimate is significantly different than for whites. The Aboriginal estimate is similar to Asians, but the large margin of error around the estimate - due to the fact that we have a much smaller sample size $(\mathrm{N}=393)$ for Aboriginal vignettes - is quite large.

10. Note as well that the American results are not dependent on the measure of racism here. Indeed, using a modern racism scale, we find very similar results. See the online appendix for models using various measures of racial prejudice.

11. These results are provided in Table A3 in the online appendix.

\section{References}

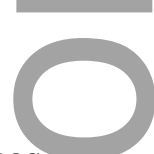

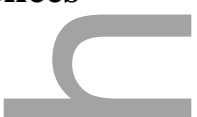

Alexander, C. \& Becker, H.J. (1978). The use of vignettes in survey research. Public Opinion Quarterly 42: 93-104.

Allport, G.W. (1958). The nature of prejudice. Garden City, NY: Doubleday.

Aarøe, L. \& Petersen, M.B. (2014). Crowding out culture: Scandinavians and Americans agree on social welfare in the face of deservingness cues. Journal of Politics 76(3): 684-697.

This article is protected by copyright. All rights reserved. 
Banting, K. \& Kymlicka, W. (eds) (2006). Multiculturalism and the welfare state: Recognition and redistribution in contemporary democracies. New York: Oxford University Press.

Banting, K. et al. (2006). Do multiculturalism policies erode the welfare state? An empirical analysis. In K. Banting \& W. Kymlicka (eds), Multiculturalism and the welfare state:

Recognition and redistribution in advanced democracies. Oxford: Oxford University Press.

Bleich, E. (2009). Where do Muslims stand on ethno-racial hierarchies in Britain and France? Evidence from public opinion surveys, 1988-2008. Patterns of Prejudice 43(3-4): $379-400$.

Blinder, S., Ford, R. \& Ivarsflaten, E. (2013). The better angels of our nature: How antiprejudice norms affects policy and party preferences in Great Britain and Germany. American Journal of Political Science 57(4): 841-857.

Blumer, H. (1958). Race prejudice as a sense of group position. Pacific Sociological Review 1: 37.

Bobo, L.(1991). Social responsibility, individualism and redistributive policies. Sociological Forum 6(1): 71-92.

Bobo, L. (2001). Racial attitudes and relations at the close of the twentieth century. In N.J. Smelser \& W.J. Wilson (eds), America becoming: Racial trends and their consequences. Washington, DC: National Academy Press.

Bobo, L. \& Fox, C. (2003). Race, racism and discrimination: Bridging problems, methods and theory in social psychology research. Social Psychology Quarterly 66(4): 319332.

Bobo, L. \& Kleugel, J. (1993). Opposition to race-targeting: Self-interest, stratification ideology or racial attitudes. American Sociological Review 58(4): 443-464.

Carmines, E.G., Sniderman, P.M. \& Easter, B.C. (2011). On the meaning, measurement and implications of racial resentment. Annals of the American Academy of Political and 
Social Science 634(1): 98-116,

Clawson, R. \& Trice, R. (2000). Poverty as we know it: Media portrayals of the poor. Public Opinion Quarterly 64(1): 53-64.

Cook, F.L. \& Barrett, E. (1992). Support for the American welfare state: The views of Congress and the public. New York: Columbia University Press.

Cornell, S. (2006). Indigenous peoples, poverty and self-determination in Australia, New Zealand, Canada and the United States. Joint Occasional Paper on Native Affairs 2006-02. Tucson, AZ: Native Nations Institute.

Crepaz, M. (2007). Trust beyond borders: Immigration, the welfare state and identity in modern societies. Ann Arbor, MI: University of Michigan Press.

Eagly, A.H. et al. (1991). What is beautiful is good, but ... : A meta-analytic review of research on the physical attractiveness stereotype. Psychological Bulletin 110(1): 109-128.

Eberhardt, J.L. et al. (2004). Seeing black: Race, crime and visual processing. Journal of Personality and Social Psychology 87: 876-893.

Evans, G. (2006). Is multiculturalism eroding support for the welfare provision: The British case. In K. Banting \& W. Kymlicka (eds), Multiculturalism and the welfare state: Recognition and redistribution in contemporary democracies. Oxford: Oxford University Press.

Faist, T. (1995). Ethnicization and racialization of welfare state politics in Germany and the USA. Ethnic and Racial Studies 18: 219-250.

Federico, C. (2005). Racial perceptions and evaluative responses to welfare: Does education attenuate race-of-target effects? Political Psychology 26(5): 683-697.

Frederico, C. \& Holmes, J. (2005). Education and the interface between racial perceptions and criminal justice attitudes. Political Psychology 26: 47-75.

Feldman, S. \& Huddy, L. (2005). Racial resentment and white opposition to race-conscious This article is protected by copyright. All rights reserved. 
programs: Principles or prejudice. American Journal of Political Science 49: 168-183.

Feldman, S. \& Zaller, J. (1992). The political culture of ambivalence: Ideological responses to the welfare state. American Journal of Political Science 36: 268-307.

Finseraas, H. (2008). Immigration and preferences for redistribution: an empirical analysis of European survey data. Comparative European Politics 6(4): 407-431.

Ford, R. (2006). Prejudice and white majority welfare attitudes in the UK. Journal of Elections, Public Opinion and Parties 16(2): 141-156.

Ford, R. (2008), Is racial prejudice declining in Britain? British Journal of Sociology 59(4):

$$
609-636 .
$$

Ford, R. (2015). Who should we help? An experimental test of discrimination in the British welfare state. Political Studies. Early View.

Fox, C. (2004). The changing color of welfare: How whites attitudes toward Latinos influence support for welfare. American Sociological Review 110(3): 580-625.

Freeman, G.P. (2009). Immigration, diversity and welfare chauvinism. Forum 7(3), ISSN (Online) 1540-8884.

Gilens, M.(1995). Racial attitudes and opposition to welfare. Journal of Politics 57(4): 9941014.

Gilens, M. (1996a). Race and poverty in America: Public misperceptions and the American news media. Public Opinion Quarterly 60(4): 515-541.

Gilens, M. (1996b). 'Race coding' and white opposition to welfare. American Political Science Review 90(3): 593-604.

Gilens, M. (1999). Why Americans hate welfare: Race, media and the politics of antipoverty policy. Chicago, IL: University of Chicago Press.

Gilliam, F.D. \& Iyengar, S. (2000). Prime suspects: The influence of local television news on the viewing public. American Journal of Political Science 44(3): 560-573. 
Gilliam, F., Valentino, N. \& Beckmann, M. (2002). Where you live and what you watch: The impact of racial proximity and local television news on attitudes about race and crime. Political Research Quarterly 55: 755-780.

Goodhart, D. (2006). Progressive nationalism. London: Demos.

Golding, P. \& Middleton, S. (1982). Images of welfare: Press and public attitudes to poverty. Oxford: Martin Robertson.

Harell, A., Soroka, S. \& Ladner, K. (2013). Public opinion, prejudice and the racialization of welfare in Canada. Ethnic and Racial Studies 37(14): 2580-2597.

Harell, A., Soroka, S. \& Mahon, A. (2008). Is welfare a dirty word? Canadian public opinion on social assistance policies. Policy Options 29(8): 53-56.

Hasenfled, Y. \& Rafferty, J. (1989). The determinants of public attitudes toward the welfare state. Social Forces 67: 1027-1048.

Henry, P.J. \& Sears, D. (2002). The Symbolic Racism 2000 Scale. Political Psychology $23(2): 253-283$.

Hjorth, F. (2015). Who benefits? Welfare chauvinism and national stereotypes. European Union Politics 17(1): 3-24.

Hurwitz, J. \& Peffley, M. (1997). Public perceptions of race and crime: The role of racial stereotypes. American Journal of Political Science 41(2): 375-401.

Hutchinson, V. (2009). Change or more of the same? Evaluating racial attitudes in the Obama era. Public Opinion Quarterly 73(5): 917-942.

Iyengar, S. (1990). Framing responsibility for political issues: The case of poverty. Political Behavior 12(1): 19-40.

Iyengar, S. (1991). Is anyone responsible? How television frames political issues. Chicago, IL: University of Chicago Press.

This article is protected by copyright. All rights reserved. 
Katz, M. (1989). The undeserving poor: From the war on poverty to the war on welfare. New York: Pantheon Books.

Kinder, D. \& Sears, D. (1981). Prejudice and politics: Symbolic racism versus racial threats to the good life. Journal of Personality and Social Psychology 40(3): 414-431.

Kluegel, J. (1990). Trends in whites' explanations of the gap in black-white socio-economic status, 1977-1989. American Sociological Review 55(4): 512-525.

Kluegel, J.R. \& Smith, E.R. (1986). Beliefs about inequality: Americans'views of what is and what ought to be, social institutions and social change. New York: De Gruyter.

Koopmans, R. (2010). Trade-offs between equality and difference: Immigrant integration, multiculturalism and the welfare state in cross-national perspective. Journal of Ethnic and Migration Studies 36(1): 1-26.

Krysan, M. (2000). Prejudice, politics and public opinion: Understanding the sources of racial policy attitudes. Annual Review of Sociology 26: 135-168.

Larsen, C.A. (2013). The rise and fall of social cohesion: The construction and deconstruction of social trust in the US, UK, Sweden and Denmark. Oxford: Oxford University Press.

Larsen C.A. \& Dejgaard, T.E. (2013). The institutional logic of images of the poor and welfare recipients: A comparative study of British, Swedish and Danish Newspapers. Journal of European Social Policy 23(3): 287-299.

Lee, W. \& Roemer, J.E. (2006). Racism and redistribution in the United States: A solution to the problem of American exceptionalism. Journal of Public Economics 90(6-7): $1027-1052$.

Lieberman, R. (1998). Shifting the color line: Race and the American welfare state. Cambridge, MA: Harvard University Press.

Luttmer, E. (2001). Group loyalty and the taste for redistribution. Journal of Political Economy This article is protected by copyright. All rights reserved. 
109(3): 500-529.

Mau, S. \& Burkhardt, C. (2009). Migration and welfare state solidarity in Western Europe. Journal of European Social Policy 19(3): 213-229.

McConahay, J.B. \& Hough, J.C. (1976). Symbolic racism. Journal of Social Issues 32(2): 23-45.

McLaren, L. \& Johnson, M. (2007). Resources, group politics and symbols: Explaining antiimmigration hostility in Britain. Political Studies 55(4): 709-732.

Mendelberg, T. (2001). The race card: Campaign strategy, implicit messages and the norm of equality. Princeton, NJ: Princeton University Press.

Misra, J., Moller, S. \& Karides, M. (2003). Envisioning dependency: Changing media depictions of welfare in the 20th century. Social Problems 50(4): 482-504.

Nannestad, P. (2007). Migration and welfare states: A survey of 15 years of research.

European Journal of Political Economy 23(2): 512-532.

Nelson, T. (1999). Group affect and attribution in social policy opinion. Journal of Politics 61(2): $331-362$.

Peffley, M. \& Hurwitz, J. (2002). The racial components of 'race-neutral' crime policy attitudes. Political Psychology 23: 59-75.

Peffley, M., Hurwitz, J. \& Sniderman, P. (1997). Racial stereotypes and whites' political views of blacks in the context of welfare and crime. American Journal of Political Science 41: 3060.

Pettigrew, T. \& Meertens, R. (1995). Subtle and blatant prejudice in Western Europe. European Journal of Social Psychology 25: 57-75.

Reeskens, T. \& Van Oorschot, W.J.H. (2012). Disentangling the 'new liberal dilemma': On the relation between general welfare redistribution preferences and welfare chauvinism. International Journal of Comparative Sociology 53(2): 120-139.

Rivers, D. \& Bailey, D. (2009). Inferences from Matched Samples in the 2008 US National 
Elections. Paper presented at the Survey Research Methods Section of the American Statistical Association, Joint Statistical Meeting.

Rossi, P. \& Nock, S. (1982). Measuring social judgments: The factorial survey approach.

Newbury Park, CA: Sage.

Rothstein, B. (1998). Just institutions matter: The moral and political logic of the universal welfare state. Oxford: Oxford University Press.

Schram, S., Soss, J. \& Fording, R. (eds) (2003). Race and the politics of welfare. Ann Arbor, MI: University of Michigan Press.

Schuman, H. et al. (1997). Racial attitudes in America: Trends and interpretations. Cambridge, MA: Harvard University Press.

Sherif, M. et al. (1961). Intergroup conflict and cooperation: The robber's cave experiment. Norman, OK: University of Oklahoma Book Exchange.

Simmons, A.D. \& Bobo, L.D. (2015). Can non-full-probability internet surveys yield useful data? A comparison with full-probability face-to-face surveys in the domain of race and social inequality attitudes. Sociological Methodology 45(1): 357-387.

Sniderman, P.M. \& Carmines, E.G. (1997). Reaching beyond race. Cambridge, MA: Harvard University Press.

Somers, M. \& Block, F. (2005). From poverty to perversity: Ideas, markets and institutions over 200 years of welfare debate. American Sociological Review 70(2): 260-287.

Soroka, S., Harell, A. \& Iyengar, S. (2013). Racial cues and attitudes toward redistribution : A comparative experimental approach. EUI Working Paper RSCAS 2013/59. Florence: European University Institute.

Soroka, S., Johnston, R. \& Banting, K. (2006). Immigration and redistribution in a global era. In S. Bowles, P. Bardhan \& M. Wallerstein (eds), Globalization and egalitarian redistribution. Princeton, NJ/New York: Princeton University Press/Russell Sage 
Foundation.

Soroka, S. et al. (2015). Migration and welfare state spending. European Political Science Review 8(2): 173-194.

Stichnoth,H. \& Straeten, K.V.D. (2013). Ethnic diversity, public spending and individual support for the welfare state: A review of the empirical literature. Journal of Economic Surveys 27(2): 364-389.

Tajfel, H. \& Turner, J.C. (1986). The social identity theory of intergroup behavior. In W.G. Austin \& S. Worchel (eds), Psychology of intergroup relations. Chicago, IL: NelsonHall.

Tan, A., Fujioka, Y. \& Lucht, N. (1997). Native American stereotypes, TV portrayals and personal contact. Journalism and Mass Communication Quarterly 74(2): 265-284.

Tesler, M. (2012). The spillover of racialization into health care: How President Obama polarized public opinion by racial attitudes and race. American Journal of Political Science 56(3): 690-704.

Van Der Wall, J., De Koster, W. \& Van Oorschot, W. (2013). Three worlds of welfare chauvinism? How welfare regimes affect support for distributing welfare to immigrants in Europe. Journal of Comparative Policy Analysis: Research and Practice 15(2): 164-181.

Van Parijs, P. (2004). Cultural diversity versus economic solidarity. Brussels: De Boeck. Vavreck, L. \& Iyengar, S. (2011). The future of political communication research: Online panels and experimentation. In R. Shapiro \& L. Jacobs (eds), Oxford handbook of public opinion and media research. Oxford: Oxford University Press.

Vavreck, L. \& Rivers, D. (2008). The 2006 Cooperative Congressional Election Study. Journal of Elections, Public Opinion and Parties 18(4): 355-366.

Winter, N. (2006). Beyond welfare: Framing and the racialization of white opinion on social This article is protected by copyright. All rights reserved. 
security. American Journal of Political Science 50(2): 400-420.

Winter, N. (2008). Dangerous frames: How ideas about race and gender shape public opinion. Chicago, IL: University of Chicago Press.

Wright, M. \& Reeskens, T. (2013). Of what cloth are the ties that bind? A multilevel analysis of the relation between national identity and support for the welfare state across 29

European countries. Journal of European Public Policy 20(10): 1443-1463.

Table 1. Mean overt racism scores

\begin{tabular}{lccc}
\hline & United States & United Kingdom & Canada \\
\hline Black & 0.450 & 0.445 & 0.363 \\
Hispanic & 0.320 & & \\
Asian & 0.188 & 0.247 & 0.202 \\
Aboriginal & 0.376 & & 0.511 \\
South Asian & 0.239 & 0.312 & 0.299 \\
\hline
\end{tabular}

Notes: Based on white, non-foreign-born respondents only (unweighted). Cells contain mean scores for a $0-1$ measure combining responses to questions on whether groups are: (a) hardworking/lazy, and (b) dependent/self-reliant.

Table 2. Direct impact of overt racism on recipient support

\begin{tabular}{lccc}
\hline & United States & United Kingdom & Canada \\
\hline Black & $-42.591 * * *(6.105)$ & $-37.436^{* * *}(4.974)$ & $0.371(5.760)$ \\
Hispanic & $-11.633(10.972)$ & & \\
& $22.405^{* * *}(6.744)$ & $15.448^{*}(6.583)$ & $1.189(5.901)$ \\
Asian & $-27.833^{* * *}(6.237)$ & & $-26.136^{* * *}(5.041)$ \\
Aboriginal & & $-13.271 *(6.091)$ & \\
South Asian & &
\end{tabular}

Notes: $* \mathrm{p}<0.05 ; * * \mathrm{p}<0.01 ; * * * \mathrm{p}<0.001$. Cells contain multilevel mixed-effects linear regression coefficients with standard errors in parentheses. Based on white, non-foreignborn respondents only (unweighted). Full models are included in Table A2 in the online appendix.

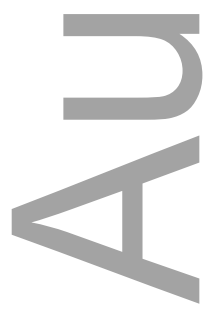

This article is protected by copyright. All rights reserved. 

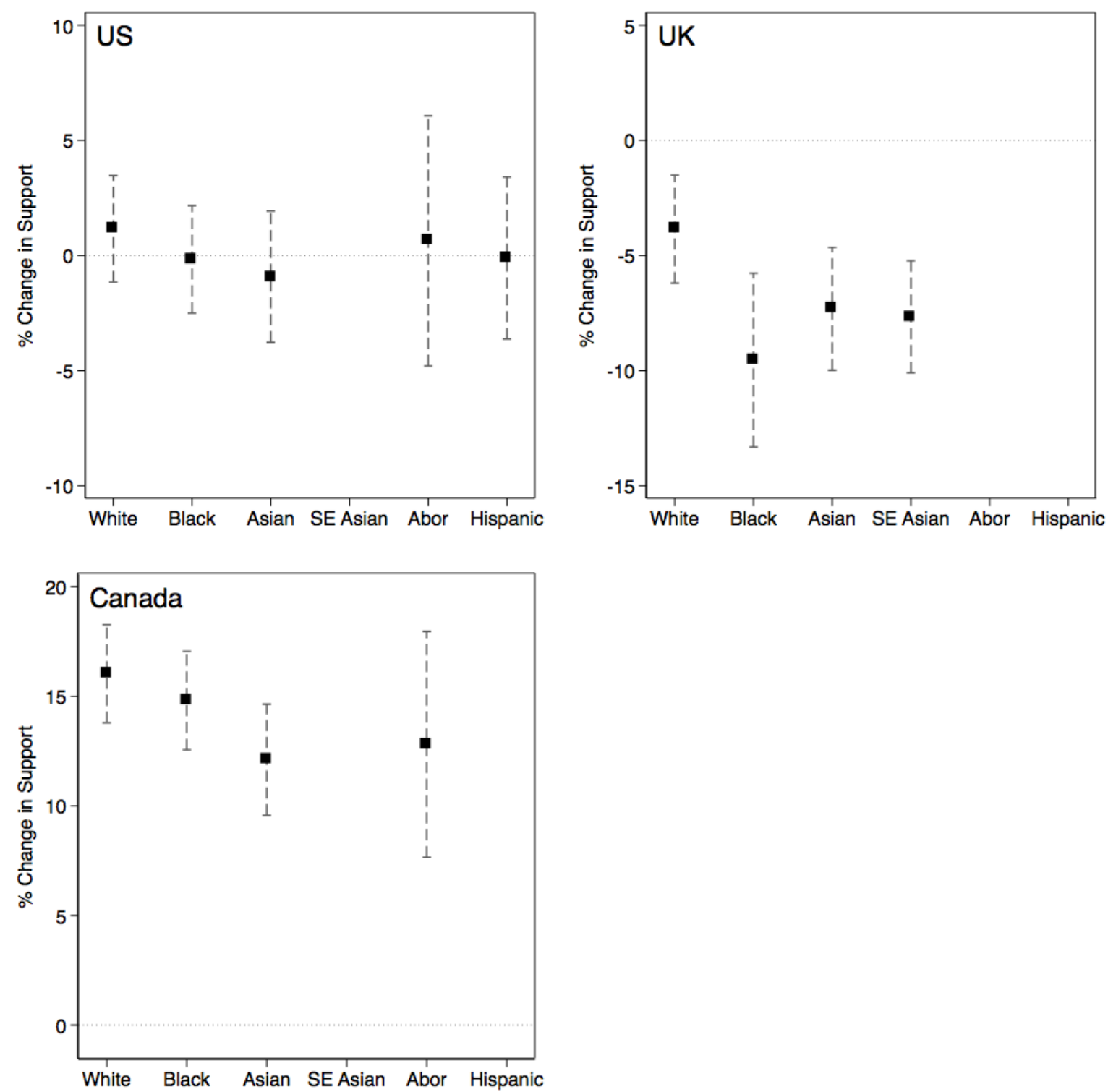

Figure 1. Mean recipient support, by recipient ethnicity.

Note: Average within-respondent, within-vignette racial effects, based on white, non-foreignborn respondents only (unweighted), all vignettes combined.

This article is protected by copyright. All rights reserved. 

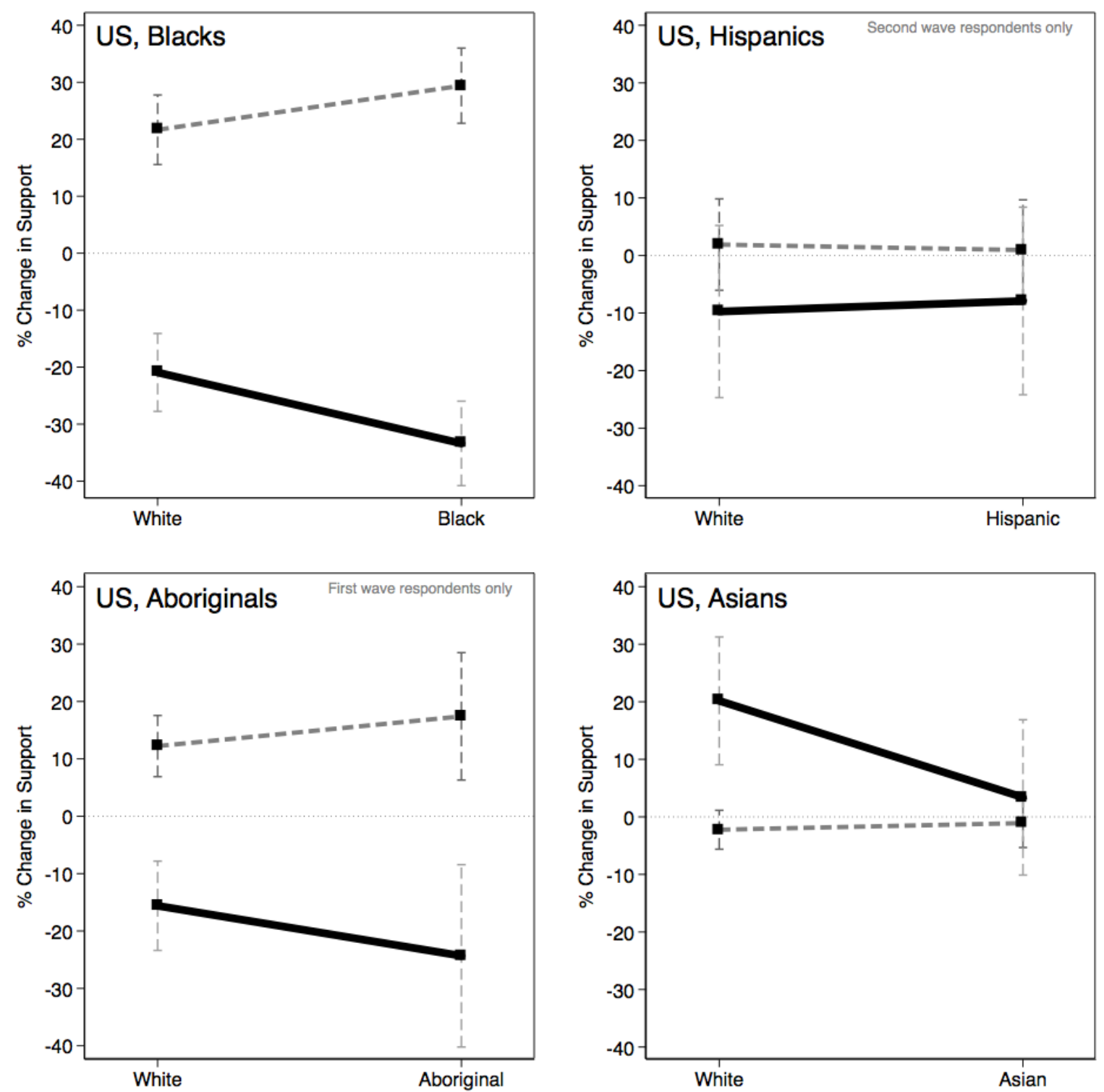

Figure 2. Treatment effects of recipient ethnicity moderated by overt racism, United States.

Notes: Average within-respondent, within-vignette racial effects, based on white, nonforeign-born respondents only (unweighted), all vignettes combined. Solid line shows the impact of Race for high-racism respondents. Dashed line shows the impact of Race for lowracism respondents.

This article is protected by copyright. All rights reserved. 

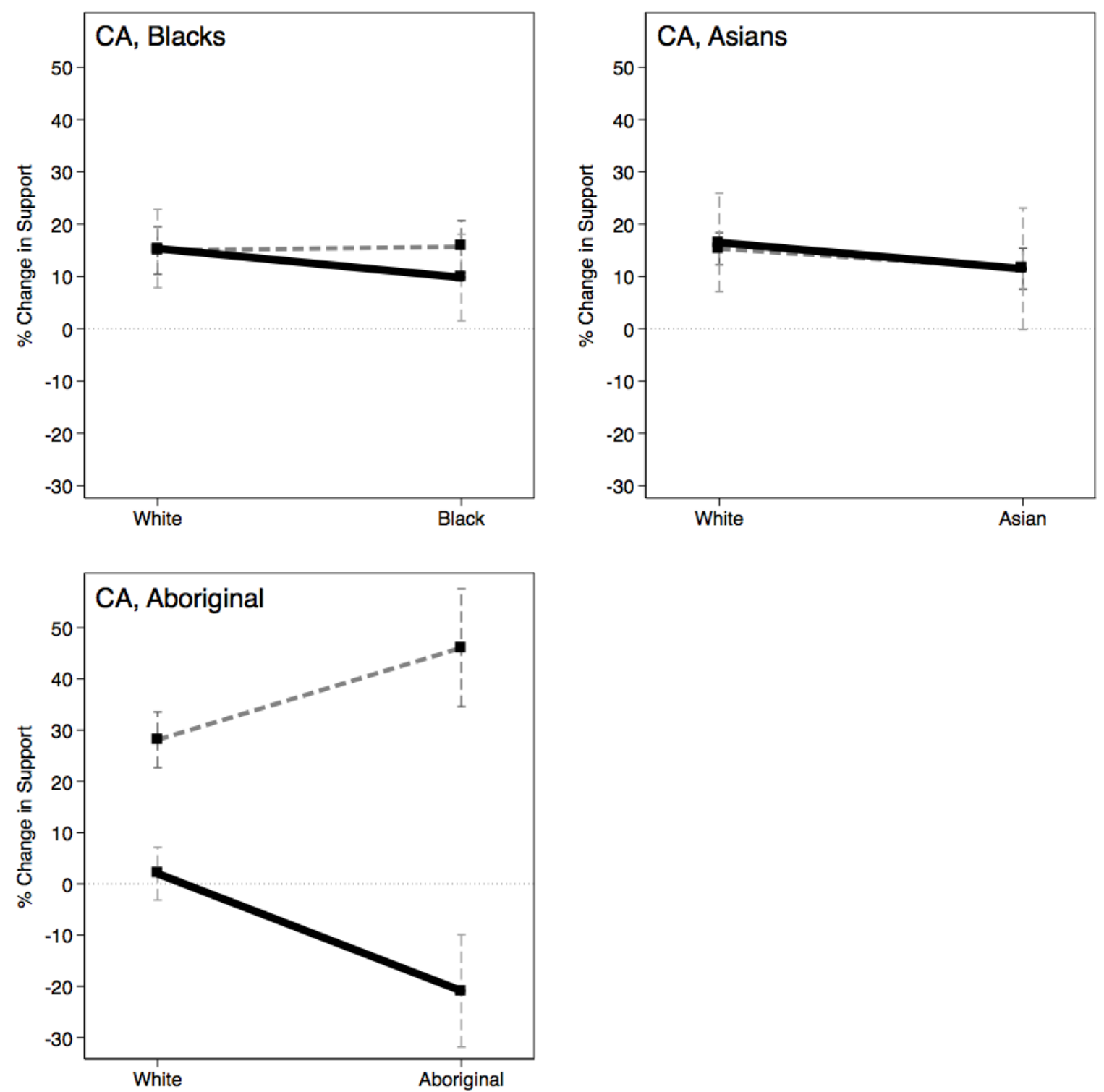

Figure 3. Treatment effects of recipient ethnicity moderated by overt racism, United Kingdom.

Notes: Solid line shows the impact of Race for high-racism respondents, based on white, nonforeign-born respondents only (unweighted). Dashed line shows the impact of Race for lowracism respondents.

This article is protected by copyright. All rights reserved. 

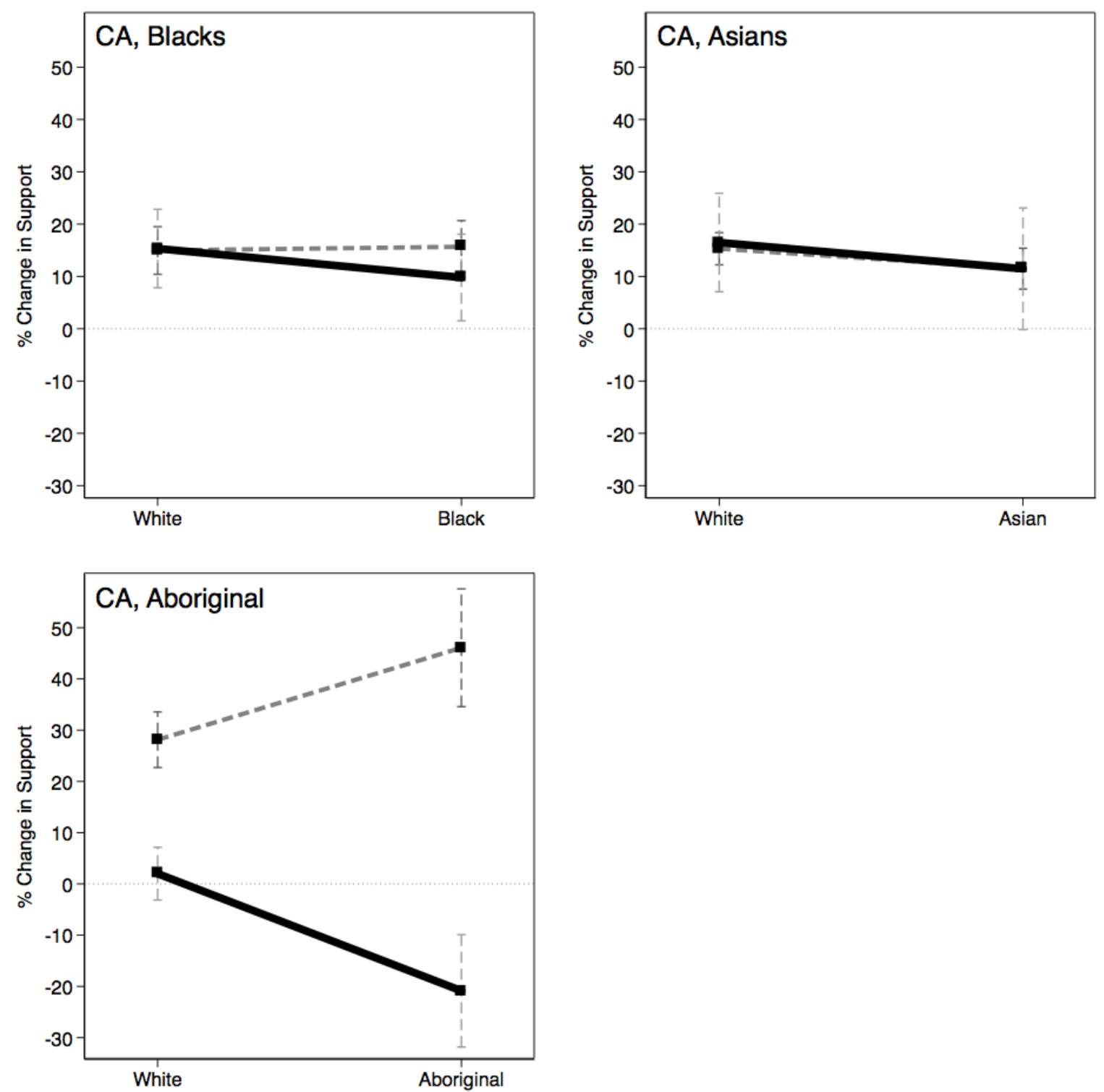

Figure 4. Treatment effects of recipient ethnicity moderated by overt racism, Canada.

Notes: Solid line shows the impact of Race for high-racism respondents, based on white, nonforeign-born respondents only (unweighted). Dashed line shows the impact of Race for lowracism respondents.

Address for correspondence: Allison Harell, Department of Political Science, University of Montreal, CP 8888, Centre-Ville, Montréal H3C 3P8, Canada. E-mail: harell.allison@uqam.ca 